DOI: $10.35757 / R P N .2012 .20 .06$

\title{
Piotr Łysakowski
}

\section{WSPÓŁPRACA STASI I SB \\ W LATACH 1950-1989 \\ - WSTĘP DO DYSKUSJI NAD PROBLEMEM}

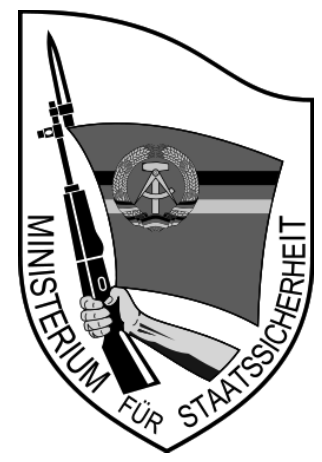

Mimo upływu ponad dwudziestu lat od upadku komunizmu obszar działania tajnych służb państw bloku pozostaje nadal niezbadany, a na pewno nie jest zbadany do końca. Upłynęło zbyt mało czasu, by odsłonić wszystkie tajemnice. Część z nich zaś na pewno została przejęta przez dzisiejsze służby różnych państw, co generalnie uniemożliwi ich, pełne, odkrycie i ujawnienie. Terenem, w zasadzie, nieznanym ${ }^{1}$ polskiej historiografii jest historia, działanie i możliwa współpraca z polskim Urzędem Bezpieczeństwa, a potem Służbą Bezpieczeństwa, wschodnioniemieckiej bezpieki Stasi. W dostępnej literaturze przedmiotu rzadko pojawiają się informacje na temat jakichkolwiek kontaktów między

\footnotetext{
1 Bardzo ciekawą publikacją (ale to, tak naprawdę, dopiero start do badania problemu) jest wydawnictwo źródłowe opracowane przez profesora Wojciecha Wrzesińskiego, które o dziwo nie odbiło się zbyt szerokim echem wśród fachowców: W. Wrzesiński (red.): (Współpraca rządu Mazowieckiego ze Stasi), Drogi do Niepodległości 1944-1956/1980 - 1989. Nieznane źródła do dziejów najnowszych Polski. Wrocław 2001.
} 
służbami PRL i NRD², nie wspominając już o ich współpracy w konkretnych sprawach. Może to wynikać z czterech przesłanek. Jedna to brak wiedzy wynikający z niedostatecznego (aczkolwiek zrozumiałego) dostępu do dokumentów związanych ze sprawą druga to możliwy brak tej współpracy, lub jej bardzo ograniczony wymiar, trzecia to wspomniane już przejęcie aktywów poszczególnych narodowych organizacji zajmujących się bezpieczeństwem państwowym, w ramach funkcjonującego „obozu socjalistycznego", przez dzisiejsze służby i utajnienie tych spraw w miarę istniejących potrzeb tych struktur. Czwartą i ostatnią zaś może być obawa historyków, a przed nimi polityków, przed wykorzystywaniem materiałów służb tajnych, które de facto mogą (lub mogłyby) być apokryfami z definicji wprowadzającymi badaczy, a także i późniejszych czytelników w błąd ${ }^{3}$. Nie jesteśmy więc w stanie, przy obecnym poziomie wiedzy, precyzyjnie określić stanu faktycznego i poziomu możliwości pełnego dostępu do dokumentów dotyczących interesują-

\footnotetext{
2 Jeśli chodzi o współpracę służb polskich i dawnego obozu socjalistycznego w zasadzie jest reguła, że informacje na jej temat są limitowane, a jeśli się gdzieś pojawiają to $\mathrm{w}$ atmosferze sensacji i są (czemu trudno się dziwić) trudne do zweryfikowania.

3 , $3 . .$.$] Z tym wiąże się kolejne pytanie: co zostało przejęte przez urząd Gaucka,$ po obaleniu muru berlińskiego? Dosłownie wszystko: akta, inne dokumenty, zarządzenia urządzenia i wyposażenie. Tam nic nie zostało zniszczone, wybrakowane. [...] Zostały przejęte laboratoria, drukarnie, maszyny do pisania, papier, druki firmowe, piecząt$\mathrm{ki}$, a nawet tusz i farba drukarska. W służbie u nowego pracodawcy kontynuuje pracę wielu funkcjonariuszy b. MBP w tym i ci, którzy zajmowali się gromadzeniem i przetwarzaniem danych przekazywanych do centrali oraz prowadzili archiwa. Gen. Markus Wolf b. szef Zarządu głównego Informacji /- wywiad MBP NRD/, mimo groźnych zapowiedzi nie poniósł żadnych konsekwencji. [...] Publikowanie wyselekcjonowanych przez urząd Gaucka dokumentów, dla wykazania skali zainteresowań służb specjalnych b. NRD sytuacją w Polsce [...] powinno być poprzedzone weryfikacją wiarygodności tych danych, według metodologii historycznej i w oparciu o: materiały polskiego Ministerstwa Spraw Wewnętrznych. [...]" z listu generała Zbigniewa Pudysza (w latach 1985-1990 minister spraw wewnętrznych w PRL - *1931+2010) do wydawnictwa „Fakt” opublikowanego w PRL w oczach STASI, t. II, Dokumenty z lat 1980-1983, wybór i opr. W. Borodziej i J. Kochanowski, Warszawa 1993, s. 158-163. Z cytowanego dokumentu wynika głęboka niewiara Pudysza w możliwość budowania jakiejkolwiek narracji o działaniach Stasi (w tym współpracy z SB, której był przecież integralną częścią) na podstawie niemieckich dokumentów. Zakłada on, trzeba to tu powiedzieć wprost, że Niemcy będą manipulowali dokumentami dawnej policji bezpieczeństwa NRD w celu destabilizowania sytuacji wewnętrznej Polski. Nie wykluczając takiej możliwości (bo tego nie można nigdy wykluczać), trzeba tu zwrócić uwagę na polityczny interes generała w chronieniu środowiska, z którego się wywodził, a mianowicie komunistów. Przy analizie jego listu należy to także poważnie brać pod uwagę. Summa sumarum, pokazuje to tylko jak trudny badawczo jest obszar, po którym staramy się poruszać.
} 
cej nas tematyki. Wspomina się co prawda o współpracy (z końcem lat pięćdziesiątych) polsko-enerdowskiej funkcjonującej na terenie Polski Ludowej i np. odnoszącej się do kwestii „łączenia rodzin”, oraz działaniu polskiej grupy roboczej przy ambasadzie PRL w stolicy NRD. Było to, jak się zdaje, działanie ograniczone, a na pewno niezbadane szczegółowo. Jak wynika z dostępnych dokumentów, w roku 1956 ustalono też „monitorowanie” działań Kościoła i wspólnot religijnych oraz wymianę informacji o tym na copółrocznych spotkaniach. Później (w połowie lat sześćdziesiątych) ustalono, że RFN będą „obserwować” (by nie mnożyć niepotrzebnie obszarów działalności operacyjnej) głównie specjaliści ze Stasi ${ }^{4}$. W połowie lat siedemdziesiątych „w centrali” na Rakowieckiej uznano, że przekazywane „nam” przez Hauptverwaltug Aufklaerung - Główny Zarząd Rozpoznania - wywiad cywilny NRD informacje o Niemczech Zachodnich nie spełniają naszych oczekiwań i postanowiono o wzmocnieniu dopływu informacji do „wydziału niemieckiego", angażując w tę działalność rezydentury wywiadu PRL z Wiednia, Berna, Genewy, Hagi, Kopenhagi i Sztokholmu. Do momentu podjęcia tej decyzji zajmowały się one innymi sprawami. Nie dość tego - rozpoczęto także "monitorowanie bratniej NRD”. Działania te jednak miały być kontrolowane przez Stasi ${ }^{5}$.

Tu na marginesie ogólna uwaga metodologiczna - wydaje się też, że $\mathrm{w}$ wielu przypadkach $\mathrm{w}$ sposób sprzeczny $\mathrm{z}$ metodami pracy historyka zakłada się, mając za podstawę badań głównie materiały Stasi, i nie dysponując przy tym pełną dokumentacją polskich służb specjalnych (pytanie, czy dostęp do tych materiałów w ogóle będzie możliwy w takim wymiarze, by cokolwiek definiować!?), przewagę wszelaką niemieckiej bezpieki i jej dominację nad „polskimi towarzyszami” także w kwestiach, w których obie służby miały ze sobą współpracować. Jak już wyżej zauważyłem, jest to podejście błędne metodologicznie i wymaga potężnej dawki, nieprzeprowadzonych jeszcze, badań, by móc jednoznacznie stwierdzić, że było właśnie tak a nie inaczej, lub odwrot-

\footnotetext{
${ }^{4}$ M. Tantzscher: «Zaczynamy tworzyć nowe, dobre tradycje wspótpracy». O kontaktach tajnych stużb NRD i PRL na podstawie akt Ministerstwa Bezpieczeństwa Państwowego NRD, w: B. Kerski, A. Kotula, K. Ruchniewicz, K. Wóycicki (red.): Przyjaźń nakazana? Stosunki między NRD i Polska w latach 1949-1990, Wrocław 2009, s. 98.

5 Z. Siemiątkowski: Wywiad a władza, Warszawa 2009, s. 100-101.
} 
nie $^{6}$. Nie opisano też jednak zmian możliwej współpracy w zależności od zmian aury politycznej między obu krajami, a zmian tych, począwszy od początku lat siedemdziesiątych ubiegłego stulecia, nie brakowało, władze niemieckiego państwa „robotników i chłopów” czuły się bowiem zdradzone przez Polskę Ludowa, która „flirtowała” z Willym Brandtem.

W dostępnej w Polsce literaturze fachowej znajdujemy wzmianki na temat spotkań i kontaktów przedstawicieli obu służb ${ }^{7}$. Nikt jednak poważnie ich nie analizował. $\mathrm{W}$ tekstach prasowych i internetowych mówi się/wspomina o współpracy, ale nie przytacza wystarczająco satysfakcjonujących i interesujących czytelnika dowodów na jej istnienie, koncentrując się na nie do końca udokumentowanych faktach ${ }^{8}$ i opisach zdarzeń9.

6 Taką właśnie postawę badawczą prezentuje w przytaczanym wyżej tekście Monika Tantzscher przekonana, jak wielu innych autorów zajmujących się problematyką służb, o omnipotencji Stasi i jej przewadze nad innym służbami „obozu postępu”.

7 Zbigniew Siemiątkowski w swej pracy Wywiad a władza wspomina np. o wyjazdach funkcjonariuszy polskich służb do NRD (w końcu lat sześćdziesiątych i na początku siedemdziesiątych). Celem tych wyjazdów było uczenie się od „będących na pierwszej linii frontu towarzyszy z NRD" metod walki z dywersją ideologiczną: Z. Siemiątkowski: op. cit., s. 240.

8 W języku polskim ukazały się, między innymi, następujące teksty prasowe i wystąpienia dotyczące Stasi - nie wyczerpują one jednak w jakimkolwiek wymiarze tematu informują zaledwie o istnieniu pewnych spraw, nie roszcząc sobie równocześnie pretensji do ich całkowitego wyjaśnienia: E. Czaczkowska: Stasi interesowało się księdzem Popiełuszka, „Rzeczpospolita”, 17 listopada 2009 (wersja internetowa gazety); Deutsche Welle - World.de, Weterani Stasi na posadach w niemieckich urzędach, w rubryce ",Polityka", 9 lipca 2009; Deutsche Welle - World.de, Lekarze w stużbie Stasi, w rubryce "Panorama, Dziennik"; Wiadomości, dziennik/świat, Komunistyczne tajne stużby kręciły porno, 28 marca 2008; B. Łoziński, Ks. Zaleski ujawni akta Stasi o inwigilacji Kościoła, „Dziennik”, 25 września 2007; F. Gańczak, A. Stankiewicz, P. Śmiłowicz: Na celowniku Stasi, „Newsweek.pl”, 5 lipca 2009; Angele Merkel promowali agenci Stasi, "Gazeta Polska”, 28 czerwca 2007; Po Europie kraża dokumenty Stasi na temat szpiegów w Watykanie, „Gazeta Prawna”, 25 września 2009; Stasi i Grot Rowecki, "Gazeta Wybrocza”, 29 listopada 2009; W. Gruna: Stasi ciagle żyje?, Lebt die Satsi immer noch?, "Gazeta Polsko-Niemiecka / Deutsch Polnische Zeitung" (www.region24.info/art_101.html); H. Labrenz Weiss: referat podczas konferencji „Radio Solidarność, 26 maja 2007 w Poznaniu. Referat wygłoszony pod tytułem: „Solidarność w teczkach Stasi. Zakres i stan badań naukowych w Urzędzie Gaucka"; Daczy Angeli Merkel strzega byli funkcjonariusze Stasi, Wiadomości 24.pl, 3 lipca 2009; B. Wieliński: Czy można było wykręcić się od donoszenia Stasi, "Gazeta Wyborcza”, 19 maja 2009 (wersja elektroniczna); idem, Agenta Stasi pilnie zatrudnię, "Gazeta Wyborcza”, 3 sierpnia 2009 (wersja elektroniczna); Tajne akta Stasi o szpiegach w Watykanie, „Wprost”, 25 września 2009; Agent Stasi autorem wydarzeń 1968 roku, „Bibuła pismo niezależne”, 25 maja 2009; P. Litka: Ksiądz Jerzy Popiełuszko. Dni, które wstrząsnęty Polska. Nieznane materiaty STASI, Kraków 2009.

9 Specjalista do spraw związanych z kwestiami funkcjonowania Stasi i autor podstawowych prac (Der Mielke Konzern - Die Geschichte der Stasi 1945-1990, München 2001; 
Nawet, co ciekawe, wzmiankowane szczegóły są tylko sygnalizowane bez głębszej analizy i rozwinięcia problemu ${ }^{10}$. Jak to się teraz mówi, "tak naprawdę" nie wiemy do końca, po lekturze tych tekstów, czy polska i enerdowska bezpieka ściśle współpracowały ze soba, czy "towarzysze z NRD” hulali po Polsce ${ }^{11}$ zupełnie bezkarnie grając na nosie ${ }^{12}$ „naszym” służbom i działając wbrew sojuszniczemu intereso-

Die Hauptamtlichen Mitarbeiter der Staatssicherheit, Personalstruktur und Lebenswelt 1950-1989/90, Berlin 2000), związanych z działaniami tej służby - Jens Gieseke - wzmiankuje w nich o Polsce i polskiej SB kilkanaście razy, a w tym ani razu w odniesieniu do współpracy obu służb, w żadnym też przypadku nie odnosi swoich informacji do wspominanych wyżej zdarzeń z polskich publikacji prasowych.

${ }^{10},[$,... Mielke i minister spraw wewnętrznych PRL, Stanisław Kowalczyk podpisali 16 maja 1974 roku w Warszawie umowę ramową o współpracy służb bezpieczeństwa. Dokument roboczy, który Mielke zabrał do Warszawy, jadąc tam na podpisanie tej umowy daje nam obraz ówczesnego stanu współpracy. Stwierdza się w nim, że współpraca wywiadów zagranicznych przynosiła - podobno - «efektywne wyniki» [...]", M. Tantzscher: «Zaczynamy tworzyć nowe, dobre tradycje wspótpracy»..., s. 103.

11, ,...] wzmożone wysyłanie delegacji do Polski należy skutecznie wesprzeć politycznie i operacyjnie. Trzeba politycznie i operacyjnie wpłynąć na to, by w ramach stosunków partnerskich wykorzystywać tylko wypróbowane osoby, które są w stanie politycznie, ofensywnie oddziaływać na swoich polskich partnerów. Przy ścisłym zachowaniu konspiracji i utrzymaniu tajności należy wprowadzać [...] pewnych i wypróbowanych IM. Informacje i rozpoznania mające znaczenie pod względem operacyjnym zdobyte $\mathrm{w}$ rezultacie politycznego i operacyjnego wsparcia oraz zabezpieczenia działalności delegacyjnej, muszą wpływać do [Centralnej Grupy] Ocen i Informacji zgodnie $\mathrm{z}$ powziętymi $\mathrm{w}$ tej sprawie ustaleniami. We wszystkich jednostkach organizacyjnych należy zapewnić stały przegląd kontaktów partnerskich i związków między obiektami i osobami odpowiedzialnymi za sprawę [kontaktów z] PRL oraz zagwarantować odpowiednie działania. Chodzi o to, by w porę rozpoznać siły kontrrewolucyjne [...]". Dokument: „1981 luty 5 Berlin - Pismo Ericha Mielkego do kierowników jednostek organizacyjnych MBP NRD dotyczące działań w związku z sytuacją w PRL, poufne", w: Przed i po 13 grudnia. Państwa bloku wschodniego wobec kryzysu w PRL 1980-1982, t. I, Warszawa 2006, s. 356, opr. Łukasz Kamiński.

${ }^{12}$ M. Tantzscher: Grupy operacyjne Stasi w krajach bloku wschodniego, „Pamięć i Sprawiedliwość" 2006, nr 1. I jeszcze jeden tekst prasowy ukazujący kulisy problemu: Niemiecki agent w otoczeniu Donalda Tuska, Dziennik. Pl Polityka, 16 maja 2008, ze strony internetowej http://wiadomości.dziennik.pl/polityka/wrtykuły. Należy tu też zwrócić uwagę na następującą kwestię: „[...] Nowe światło na przeszłość Jaruzelskiego rzuca ujawniony przez historyka Wojciecha Sawickiego dokument, odnaleziony w archiwach b. służby bezpieczeństwa NRD. W raporcie enerdowskiego kontrwywiadu wojskowego Stasi z 14 marca 1986 r. Niemcy charakteryzują generała jako aktywnego i wartościowego konfidenta, który w roku 1952 został pozyskany przez kpt. Kiszczaka jako «nieoficjalny współpracownik», przez niego zaprzysiężony i wykorzystany do wykonania zadań kontrwywiadowczych [...]". Przytoczony cytat z artykułu Zbigniewa Branacha zatytułowanego Tajemnice TW «Wolskiego» herbu Ślepowron, umieszczonego w „Naszym Dzien- 
wi $^{13}$, a w swoim własnym, jak twierdzi jeden z internautów zajmujących się tematyką niemiecką: „,...] Według Urzędu ds. Akt STASI w Polsce w czasach PRL działało przynajmniej 500 agentów STASI. Szpiclowanie sąsiedniego kraju przez NRD rozpoczęło się wraz z wyborem w roku 1978 kardynała Wojtyły na papieża. STASI infiltrowało przede wszystkim Solidarność. W czasie stanu wojennego pośród kurierów Solidarności, którzy przesyłali wiadomości z Polski na Zachód byli też agenci STASI. STASI działało w Polsce niezależnie od polskiej bezpieki. Większość zgromadzonych wówczas materiałów podobno zniszczono. Jednak badaczom z dawnego Urzędu Gaucka i tego pod rządami Birthler udało się ustalić tożsamość części ówczesnych agentów”. [...] „wiadomo, że lista szpiegów STASI na całym świecie znajduje się od dawna w posiadaniu CIA. Dopiero w 2003 roku Amerykanie przekazali część tych informacji rządowi RFN”. [...] „Udało się już ustalić nazwiska niektórych posłów do Bundestagu, którzy kiedyś pracowali dla STASI”. [...] „Agent STASI Detlef Ruser [Henryk], który mieszkał w Polsce zbliżył się do środowiska, które wydawało solidarnościowe pismo «Samorządność» między innymi do Donalda Tuska. Spotykał się z redaktorami pisma, przychodził na spotkania Klubu Myśli Politycznej im. Konstytucji 3 Maja $[\ldots]^{\prime 14}$. Czy SB w końcu i wbrew wyżej cytowanym opiniom udzielało Stasi jakieś pomocy ${ }^{15}$ i jaki miałby być jej, szeroko rozumiany, cel i obszar ich współpracy, gdyby tak było!? Czy w końcu może zwornikiem współ-

niku", 15 czerwca 2011, prowokuje do pytania, skąd towarzysze z NRD posiadali taką informację, od swoich polskich „przyjaciół” lub może sowieckich, czy w końcu pozyskali ją od swojej agentury!? Uzyskanie odpowiedzi na tak postawione pytanie mogłoby rozwiązać wiele problemów stojących przed badaczami interesującego nas tematu.

${ }^{13}$ Twierdzenia o „własnych” akcjach Stasi prowadzonych na terenie Polski w latach siedemdziesiątych i osiemdziesiątych pojawiają się w pracach Henryka Piecucha i sensacyjnych publikacjach prasowych - miały być one związane z kwestiami „Skarbu z Gór Sowich” i możliwymi poszukiwaniami „Bursztynowej Komnaty”. Nie należy zapominać też o jej aktywności na terenie Polski w przeddzień stanu wojennego - zob. przypisy 15,16 i 22 poniżej.

${ }^{14}$ Najlepszy werbownik agentów Stasi byt blisko Tuska, tekst z internetowego "Salonu 24" zamieszczony „na nim” 11 marca 2011 przez Marka Mojsiewicza, odnośny fragment pochodzi według autora tekstu z tygodnika „Forum”.

${ }^{15}$ Monika Tantzscher twierdzi, że w drugiej połowie lat siedemdziesiątych i pod koniec tej dekady: „[...] Polacy spełniali te życzenia z coraz większą gotowością do współpracy. [...] przynajmniej jeśli chodzi o kontrolowanie opozycjonistów [...]", M. Tantzscher: «Zaczynamy tworzyć nowe, dobre tradycje wspótpracy»..., s. 106. 
pracy był wspólny (jeśli był!?) interes klasowy i wynikająca z tego pomoc udzielana „stronie trzeciej” w realizacji jej „klasowych celów i zamiarów”"16!? Pytania te dotyczą zarówno okresu „Wiosny Solidarności w Polsce", którą Erich Mielke miał rzekomo przewidzieć, jak i czasów dużo wcześniejszych $^{17}$. W tym także i tych o epokowym znaczeniu, jakim był wybór Karola Wojtyły na Stolicę Piotrową w roku 1978 oraz także przełomu lat 1989-1990. Wszystko owiewa mgła przysłowiowej tajemnicy. Zbi-

${ }^{16} \mathrm{~W}$ różnych tytułach prasowych pojawiają się liczne wzmianki o możliwej aktywności SB mającej związek z zamachem na Ojca Świętego Jana Pawła II w maju 1980 roku. W tym kontekście wspomina się o współpracy SB ze Stasi „[...] jeśli śledztwo [chodzi o śledztwo prowadzone przez katowicki oddział IPN - P.Ł.] w sprawie zamachu na polskiego Papieża zostanie umorzone, a nad sprawą zapadnie urzędowa zasłona milczenia, nigdy nie zostaną wyjaśnione przynajmniej dwa istotne wątki. [...] Pierwszy dotyczy wiedzy zgromadzonej w archiwach watykańskich, głównie ustaleń watykańskiego «łowcy szpiegów» jezuity Roberta Grahama. Na dokumenty te powoływał się John Kohler - oficer wojskowego wywiadu USA [...] gdy w wywiadzie dla dziennika «La Stampa» stwierdził, że w zamach zamieszani byli także polscy duchowni. Kohler twierdzi również, że stosowano okrężną drogę zadaniowania agentów, by zwieść wywiady zachodnie. Zadania dla polskiej agentury miały przechodzić przez niemiecką Stasi, a kopie tych operacji trafiały do archiwów węgierskich [...]", Al. Ścios: Święty umorzony, „Gazeta Polska”, 9 marca 2011, nr 10.

${ }^{17}$ Zwraca na to uwage Zbigniew Siemiątkowski w cytowanej już pracy Wywiad a władza, szczególnie w kontekście działań Henryka Sokolaka ( $\left.{ }^{*} 1916+1984\right)$ zaprzyjaźnionego z licznymi niemieckimi komunistami pracującymi w enerdowskim aparacie bezpieczeństwa, jednego z dyrektorów Departamentu I Ministerstwa Spraw Wewnętrznych w latach 1961-1969 (przy okazji wypada zwrócić uwagę na różnice w dacie urodzenia tego funkcjonariusza - A. Kochański w PSB podaje rok 1916, Wikipedia podaje rok 1921 błędnie informując swych czytelników o prawdziwym nazwisku Sokolaka, które miało brzmieć według jej autorów "Mikołajczyk”, podczas gdy faktycznie brzmiało „Mikołajczak” - wspominam o tym, by uświadomić czytelnikowi z jak trudną materią mamy do czynienia, skoro nawet w odniesieniu do tak podstawowych faktów mamy problemy). Dla wyjaśnienia należy tu dodać, że błąd popełniany przez autorów Wikipedii może być wynikiem świadomej działalności Sokolaka. Zmiana faktycznej daty urodzenia miała utrudnić jego identyfikację, i m.in. ukryć jego działalność, jaką prowadził podczas pobytu w Buchenwaldzie, gdzie był wykonującym wyroki śmierci na obozowych zdrajcach. Henryk Sokolak był także „bohaterem drugiego planu” jednej z akcji Stasi prowadzonej na terenie Polski bez zgody i wiedzy jej władz, gdy jej agenci porwali w Warszawie urzędniczkę ambasady RFN; by zapobiec politycznemu skandalowi szef PRL-owskiego MSZ Stefan Olszowski miał go prosić o interwencję (wchodziły tu w grę, wspominane już, jego dawne kontakty z niemieckimi komunistami). Sokolak miał odpowiedzieć, że nie będzie: „,[...] z nimi rozmawiał tylko pójdzie i ich opierdoli [...]”. Jak powiedział, tak zrobił, a na dodatek przyniosło to efekty - porwana osoba odzyskała wolność. Zdarzenie to opisuje sam Olszowski: How are you doing Mr. Olszowski? Ze Stefanem Olszowskim rozmawiaja Andrzej Mroziński i Bogdan Rupiński, Warszawa 2008 oraz Z. Siemiątkowski: op. cit., s. 180-183. 
gniew Siemiątkowski w wydanej ostatnio (Warszawa 2009), interesującej, choć nie wolnej od uproszczeń, książce: Wywiad a władza ${ }^{18}$ wzmiankuje kilka razy o kontaktach Stasi i SB. Nie są to jednak informacje, na których można by od razu budować jakiekolwiek hipotezy badawcze.

Można nawet zaryzykować twierdzenie, że stosunki między „bratnimi” czekistami znad Wisły i Sprewy były zgoła nieciekawe: „[...] enerdowska «STASI» i jej służba wywiadowcza nie miała zbytniego zaufania do polskiego wywiadu ${ }^{19}$. Wzajemne relacje [...] szef HVA [Markus Wolf - P.Ł.] określał mianem «delikatnych wymagających dużych umiejętności szpiegowskich i dyplomatycznych» [...] Większość wyższych oficerów wywiadu enerdowskiego traktowała Polskę jako «wrogie państwo», które słabo powiązane politycznie z krajami bloku wschodniego, swoją polityką zbliżenia z zachodem pragnęło «popsuć strategiczną współpracę NRD ze Związkiem Radzieckim»" ${ }^{20}$. Dawał temu zresztą wyraz z końcem lat osiemdziesiątych sam szef Stasi Erich Mielke podczas jesiennego spotkania w Berlinie ${ }^{21}$, które odbyło się w roku 1988. Wcześniej zaś nakazywał swoim podwładnym „sondowanie” nastrojów wśród kierowników i pracowników polskiego aparatu bezpieczeństwa ${ }^{22}$

\footnotetext{
${ }^{18}$ Z. Siemiątkowski: op. cit.

${ }^{19}$ Ten brak zaufania miał skutkować budową: „[...] własnej sieci agentów w kraju sąsiada [...]", M. Tantzscher: "Zaczynamy tworzyć nowe, dobre tradycje wspótpracy»..., s. 118.

${ }^{20}$ Z. Siemiątkowski: op. cit., s. 101-102.

${ }^{21}$, ,[...] podczas plenarnego spotkania [...] Mielke w ostrych słowach skrytykował [...] wydarzenia w Polsce, określił PRL najsłabszym «ogniwem» w systemie państw socjalistycznych, zaatakował władze w Warszawie za prowadzenie polityki ustępstw, co $\mathrm{w}$ rezultacie miało prowadzić do «rozwalenia socjalizmu» [...] groził, iż w sytuacji, kiedy «towarzysze polscy nie radzą sobie» to trzeba zastanowić się jak można im pomóc [...] Markus Wolf, który przybył na pożegnalną kolację, starał się być miły dla polskich kolegów, aby w ten sposób zatrzeć fatalne wrażenie, jakie na nich zrobiło wystąienie [...] Mielkego", ibidem, s. 354-355.

22, ,...] Należy niezwłocznie sprawdzić, jakie kontakty z pracownikami na kierowniczych stanowiskach i z innymi członkami organów ochrony bezpieczeństwa istnieją lub istniały i mogłyby być podjęte w sposób zalegendowany. Należy przy tym dowiedzieć się, jaki jest ich stosunek do obecnych procesów w kierownictwie partii i rządu, szczególnie do konieczności walki z wrogami. [...] Należy wysondować, jakie poglądy są reprezentowane wśród kierowników względnie wśród innych pracowników organów bezpieczeństwa na temat koniecznych lub celowych działań ze strony bratnich organów w wypadku przygotowania i przeprowadzenia zdecydowanych akcji przeciwko wrogom. W zależności od postawy rozmówcy, do rezultatów rozmów z kierownikami i pracownikami organów bezpieczeństwa należy w ramach własnego zakresu odpowiedzialności powziąć decyzje o utrzymaniu i rozbudowie tych kontaktów [...]", 1981 paź-
} 
- interesujące byłoby pytanie, jak pracownicy resortu Mielkego mieli to robić!? ${ }^{23}$ Zwrócić należałoby też uwagę na to, że biografia tego ostatniego ${ }^{24}$ nie zawiera $\mathrm{w}$ indeksie nawet nazwiska Gomułki (np. w kontekście grudniowych umów PRL z RFN) czy Światły, którego ucieczka musiała być trudna do zaakceptowania przez Stasi" ${ }^{25}$, bo miała miejsce na terenie jej działania i w polu jej obserwacji, działalności operacyjnej. W indeksach tej biografii nie występują także takie pojęcia jak Polska, Polska Ludowa, PRL czy UB lub SB. Także z moich prywatnych rozmów z funkcjonariuszami polskiej „,bezpieki”, przeprowadzonych kilka lat temu, wynikała spora niechęć (tym razem naszych "towarzyszy") do Stasi i generalnie "niemieckiego państwa robotników i chłopów”, zapamiętałem z nich sformułowanie: „staraliśmy się - jeśli nie było to konieczne - nie dzielić się z nimi swoją wiedzą" ${ }^{26}$. Jeśli do tego wszystkie-

dziernik 24, Berlin - Pismo Ericha Mielkego do kierowników jednostek organizacyjnych MBP NRD dotyczące działań polityczno-operacyjnych w związku z sytuacją w PRL, poufne, w: Przed i po 13 grudnia..., t. II, s. 338.

${ }^{23} 1981$ listopad 18, Warszawa - Plan pracy Grupy Operacyjnej Warszawa na rok 1982, w: Przed i po 13 grudnia..., t. II, s. 359-367 oraz kolejny dokument z t. II tej pracy: 1981 listopad 25, Berlin - Plan pracy Referatu 1 Grupy Roboczej 4 Wydziału Głównego II MBP NRD na rok 1982, s. 374-377.

${ }^{24}$ H. Schwan: Erich Mielke - Żywot w stużbie STASI, Warszawa 2001.

${ }^{25}$ Nawet $\mathrm{w}$ tej sytuacji moglibyśmy doszukiwać się elementów możliwej współpracy między UB a Stasi. Swiatło bowiem, jak domniemywa Paweł Machcewicz w swej pracy: «Monachijska menażeria». Walka z Radiem Wolna Europa wydanej w Warszawie w roku 2007, twierdził, że: „[...] w grudniu 1953 r., przyjechał ze swoim zwierzchnikiem [do Berlina Wschodniego - P.Ł.] Anatolem Fejginem [...] w celu uzgodnienia z szefem wschodnioniemieckiej bezpieki Erichem Mielkem zlikwidowania Wandy Pampuch-Brońskiej [...]. W raporcie Fejgina sporządzonym wkrótce po zniknięciu Światły rozpracowanie Brońskiej i możliwa pomoc ze strony służb wschodnioniemieckich były wymieniane jako główny wątek rozmów z Mielkem [...]", s. 105.

${ }^{26}$ Mój rozmówca zatrudniony w Departamencie IV MSW od roku 1977-1978 do „weryfikacji” (w ciągu dziesięciu lat służby awansował od podporucznika do majora - tak więc był, chyba, dobrym i rokującym duże nadzieje funkcjonariuszem) w rozmowie przekazał mi cytowaną wyżej informację, jak i parę innych wiadomości dotyczących funkcjonowania resortu (szczególnie na przełomie lat 1989/1991). Zastrzegł sobie przy tym całkowitą anonimowość i ostrzegł, że w przypadku ujawnienia go jako źródła mojej wiedzy wszystkiemu zaprzeczy i wyprze się rozmowy ze mną. Jak wynikało z jego wypowiedzi, bał się, przy tym mniej wymiaru sprawiedliwości niepodległej Rzeczpospolitej niż swoich byłych kolegów (padły w jej trakcie słowa „...przecież jak powiem, to oni mnie zabiją..."). Pewnej refleksji wymaga też, czy to, o czym napisałem wyżej, dotyczyło tylko kontaktów służb „zajmujących się" kwestiami konfesyjnymi czy w ogóle struktur bezpieczeństwa w obu krajach? Tak na marginesie wydaje się być bardzo istotnym postulatem (jeśli będzie to fizycznie możliwe) przeprowadzenie wywiadów/rozmów z funkcjonariuszami Stasi, którzy mieli kontakty z Polską i Polakami. 
go dodamy wyraźny brak zaufania (od początku istnienia „bastionu socjalistycznego na zachodnich rubieżach wspólnoty") między przywódcami PRL i NRD ${ }^{27}$ to znajdziemy się w sytuacji, w której będzie można powiedzieć, że pod płaszczykiem oficjalnie deklarowanej doskonałej koegzystencji toczyła się między Polską Ludową a NRD zaciekła rywalizacja nie tylko o podłożu ideologicznym i ekonomicznym, ale także i (bardzo ważna) ta na podłożu historycznym związana z powojennymi zmianami terytorialnymi i „polskimi ranami wojennymi” spowodowanymi przez Niemców i ich postępowaniem w okupowanej Polsce w latach 1939-1945 ${ }^{28}$. Depozytariuszem dla obu stron był w tym przypadku ZSRR i jego przywódcy rozgrywający, a może nawet inspirujący w jakimś stopniu te animozje. Można domniemywać, że w takiej politycznej aurze współpraca służb mogła być trudna ${ }^{29}$ i możliwe, że w zasadzie mogła być także, na dłuższą metę, wykluczona, chyba że realizowana po nakazach „radzieckich”, jak wtedy mówiono. Trzeba więc zrobić wszystko (na tyle, na ile jest to możliwe), by tezę tę udowodnić lub obalić. Zrobić to można stawiając następujące pytania badawcze i próbując udzielić na nie odpowiedzi:

(a) jeśli istniała współpraca między UB/SB a STASI, to w jakich obszarach funkcjonowania tych służb i co powodowało, że miała ona miejsce (na przykład) w kwestiach „kościelnych”, a nie innych lub odwrotnie?;

(b) dlaczego istniała (jeśli istniała) właśnie w tych, a nie innych obszarach?;

(c) jak długo trwała, jakie były przyczyny jej nawiązania, a jakie przyczyny przerwania, jeśli takie były?;

${ }^{27} \mathrm{O}$ warunkowanej historycznie niechęci polskich „Genseków” do ich wschodnioniemieckich odpowiedników wspominają w swych wywiadach rzekach i wspomnieniach Walery Namiotkiewicz, Mieczysław F. Rakowski, Edward Gierek.

${ }^{28}$ Jak się zdaje, w opiniach i w świadomości "towarzyszy” z NRD już sama przynależność do grupy państw socjalistycznych zwalniała ich automatycznie z odpowiedzialności za popełnione przez Niemców zbrodnie wojenne.

${ }^{29}$ Ciekawym przykładem koniunkturalnej współpracy obu służb, gdzie cele były (wydawałoby się) zupełnie przeciwstawne, byłby tu "problem Adżubeja”, kiedy polska i niemiecka bezpieka miały wzajemnie wykorzystując się zagrać „sprawą” wobec „radzieckich”, co skończyło się „dymisją" Chruszczowa - pytanie jednak, czy opisywana przez historyków sprawa nie jest kolejną mistyfikacją. 
(d) czy była ona podyktowana tylko dominantą ideologiczną, czy odgrywały tu rolę $\mathrm{t}$ także inne (oprócz wspomnianych ideologicznych) czynniki?;

(e) jaki był wpływ „radzieckich towarzyszy” na jej funkcjonowanie i przebieg ${ }^{30}$ ?;

(f) jakie korzyści (lub szkody) wynikały dla obu służb z tej współpracy?;

(g) jak oceniana była (możliwa) współpraca na najwyższych szczeblach władzy?;

(h) gdzie, geograficznie, mogła koncentrować się możliwa współpraca, czy był to obszar obu krajów, czy działano poza terytorium PRL i NRD?;

(i) czy miały miejsce jakieś wspólne przedsięwzięcia obu służb rozróżniam tu pojęcia współpraca i wspólne przedsięwzięcia?;

(j) czy współpracowano w kwestii szkolenia terrorystów - wiemy przecież, że Stasi „zajmowała się” szkoleniem różnych formacji terrorystycznych, a i jej kontrakty z RAF (Rote Armee Fraktion - Frakcja Czerwonej Armii) ${ }^{31}$ nie są dziś tajemnicą.

(k) czy jest możliwe zdefiniowanie współpracy (jeśli taka była) w okresie "przełomu”?

${ }^{30}$ Wszyscy badacze problematyki określają poziom uzależnienia „służb bratnich krajów” od KGB i innych siłowych struktur ZSRR jako duży. Niektóre publikacje ukazujące się dzisiaj opisują ten stan bardzo konkretnie: „[...] Instrukcja pracy tzw. wywiadu PRL, przygotowana przez KGB w 1980 roku, dobitnie świadczy, że był on ogniwem megasłużb sowieckich. Zgodnie z tą instrukcja, KGB i SB prowadziły wspólnie długofalowe działania operacyjne w celu: „wywierania wpływu na papieża, pogłębiania różnic poglądów między Watykanem a Stanami Zjednoczonymi, pogłębiania wewnętrznych różnic w Watykanie, analizowania, planowania i prowadzenia działań operacyjnych szkodzących watykańskim planom umocnienia kościołów i rozwoju nauki religii w krajach socjalistycznych, wykrywania kanałów, którymi Kościół katolicki w Polsce zwiększa swe wpływy i podsyca działalność Kościoła w Związku Sowieckim. [...]", Al. Ścios: op. cit.

${ }^{31} \mathrm{O}$ związkach Stasi z RAF wspominają w swych pracach na przykład: A. Mueller, A. Kanonenberg: Die RAF - Stasi - Connection, Berlin 1992; B. Peters: RAF, Terrorismus in Deutschland, Stuttgart 1991; T. Wunschik: Baader-Mainhofs Kinder. Die zweite Generation $\operatorname{der} R A F$, Opladen 1997. Ostatnio (wiosna i jesień 2010) pojawiła się opublikowana przez wydawnictwo Pruszyński i S-ka i dostępna na stronie internetowej „Salon 24“ publikacja Witolda Gadowskiego i Przemysława Wojciechowskiego zatytułowana Tragarze śmierci, będąca fragmentami przygotowywanej do druku książki. Przy wszystkich wątpliwościach dotyczących i fachowości Autorów w odniesieniu do omawianych przez nich kwestii, i jakości ich pisarstwa postanowiłem, w załączniku (s. 133-136) przytoczyć fragmenty tej publikacji z 24, 25, 26 września 2010 roku, ważne są bowiem tutaj przytaczane fakty, a nie forma ich przedstawienia i używane przy tym argumenty. 
Postawione pytania tworzą niezmiernie interesujący obszar badawczy, będący swoistą Terra incognita, którym należałoby się pilnie zająć. Do dyspozycji mamy szeroką, choć niezbadaną szczegółowo, bazę źródłową znajdującą się w Instytucie Pamięci Narodowej oraz Urzędzie Gaucka (dziś Birthler) oraz szczegółowe opracowania dotyczące działalności obu służb. Kończąc, uważam za uprawnione i niezmiernie ważne postawienie pytania (i raczej nie stawianego - w przeciwieństwie do publicystów - przez historyków) o zależność rozwoju sytuacji politycznej w Polsce i relacji naszego kraju ze światem zewnętrznym w kontekście „zawartości” „polskiej części” archiwów Stasi. Ale to - jak mawiał klasyk - już zupełnie „inna historia” ${ }^{32}$.

\section{Załącznik}

[...] Intuicyjnie czuliśmy, że współpraca najbardziej krwawej grupy terrorystycznej w Europie - zachodnioniemieckiej RAF, Frakcji Czerwonej Armii z polską bezpieką jest najbardziej „gorącym kartoflem” z przeszłości. Wszyscy oficerowie, z którymi rozmawialiśmy, z wielkim zaangażowaniem się tego wypierali. To zaangażowanie wydało się nam podejrzane. $Z$ zapału, $z$ jakim przekonywali nas, że nic takiego nie miało miejsca, wywnioskowaliśmy, że układy pomiędzy SB i RAF musiały istnieć! Dziś w Polsce pewnie mało kogo to obejdzie, ale jeśli uda nam się udowodnić taki fakt, to po pierwsze trzeba będzie zmienić podręczniki historii, a po drugie zostanie stworzona możliwość oskarżenia władz PRL o wspieranie terroryzmu, a tym zajmują się międzynarodowe trybunały! Coraz więcej poszlak i mglisty, ale coraz bardziej konkretny obraz, jaki się z nich wyłaniał, przygnał nas do dawnej siedziby Stasi w Berlinie. Wszechwiedząca NRD-owska bezpieka, której oczkiem w głowie była występująca przeciwko porządkowi społecznemu w RFN Rote Armee Fraktion, musiała wiedzieć o kontaktach terrorystów z polskimi służbami. A jeśli wiedziała lub współpracowała z PRL-owską bezpieka, to w pedantycznie prowadzonym archiwum wschodnioniemieckiej służby musiał zachować się jakiś ślad tego... Dokumenty bezpieki są jak linie papilarne - nigdy do końca nie znikają. [...] Dotarło do nas, że bez pomocy kogoś z dawnych służb specjalnych PRL nie uda nam się rozwiązać zagadki pobytu terrorystów RAF na Mazurach. Jeśli pobyt ten był fragmentem większej całości w ramach polsko-NRD-owskiej operacji specjalnej, to osoba, u której musimy szukać wsparcia, z pewnością pochodzi ze ścisłego kierownictwa polskich służb. Tylko ktoś taki może mieć wiedzę

${ }^{32}$ Marek Mojsiewicz: Ambasador Niemiec grozi gazecie, "Rzeczpospolita”, 29 lutego 2012 (wyd. elektroniczne). 
na ten temat. Jeśli jednak $\mathrm{w}$ polskich archiwach nie ma ani słowa o podobnej operacji, to wniosek nasuwa się sam. Polskie służby nie chciały, aby współpraca z niemieckimi terrorystami wyszła kiedykolwiek na jaw. Jeśli się nie mylimy, to problem, który rysuje się przed nami, należy do trudnych i grząskich. [...] Mijają dni, a my odbywamy kolejne spotkania, na których wypijamy litry kawy. Naszymi rozmówcami są ludzie dawnych polskich służb. Dwie kategorie tych ludzi. Ci, którzy są na „emeryturze”, i ci, którzy mają w firmie jeszcze coś do zrobienia. To świat podwójnych zasłon i krzywych luster. Czasem więcej mówi lekki grymas, intonacja głosu niż wypowiadane słowa. Nie ma klucza do rozumienia takich sytuacji. Niekiedy pomaga jedynie intuicja i nieodgadnione interesy, które sprawiają że ktoś szepnie podpowiedź. Ktoś pokaże kierunek, posteruje amatorami w pożądanym przez siebie kierunku.

Staramy się zdobyć jakieś informacje, nie zdradzając jednak zbyt wiele z tego, czym się zajmujemy. Ani słowem nie wspominamy także o niemieckim dokumencie. Żadne z tych spotkań nie przybliża nas jednak choćby o milimetr do rozwiązania zagadki. Większość esbeków i ludzi wywiadu pytana o pobyt terrorystów z RAF w Polsce zawsze odpowiadała w ten sam sposób - „to niemożliwe!". I co z tego, że czasami wydaje się nam, iż ktoś kłamie, coś ukrywa. Może to tylko nasze subiektywne odczucie? Może za bardzo chcemy potwierdzenia naszej teorii? [...] - Co was sprowadza? - spytał Czesław Kiszczak, przysuwając ku nam półmisek z ciastami.

Rozpoczęliśmy nasze opowiadanie. Powoli, stopniowo przybliżaliśmy generałowi temat, którym się zajmujemy. Nie przerywał nam, milczał, kiwając od czasu do czasu ze zrozumieniem głową. My z kolei staraliśmy się opowiadać bez emocji, bez używania słów takich jak mordercy, komuniści czy ukrywanie albo współudział, zamieniając je na: członkowie RAF, buntownicy czy pobyt. Kiedy skończyliśmy, podaliśmy generałowi niemiecki dokument. Wziął go ostrożnie. Czytał uważnie, powoli przekładając kolejne kartki. [...] Trwało to kilka, może kilkanaście minut. Przez ten czas generał nie odezwał się ani słowem, nie zadał żadnego pytania. [...] Kiedy skończył, zwrócił nam dokument, poprawił się $\mathrm{w}$ fotelu i zapytał:

- Skąd to macie?

- Nie z Polski, panie generale - odpowiedzieliśmy niemal jednocześnie.

- Znaleźliśmy ten dokument w Berlinie, w Instytucie Gaucka.

- Tak... - Generał zawiesił głos. Po czym dodał: - To wywiad.

- Wywiad? - zapytał Witek.

- Tak, Departament I MSW, polski wywiad. Jeśli chcecie dowiedzieć się czegoś więcej o tej sprawie, pytajcie ludzi z Departamentu I, jeśli ktoś stał za tą sprawa, to mogli być tylko oni. To ich robota - zawyrokował.

- Ale w dokumencie, który pan czytał, jest informacja, że pobyt ludzi RAF na Mazurach ochraniany był przez milicjantów. Więc może Dwójka, kontrwywiad? - mnożyliśmy wątpliwości.

- Tak, to prawda, ale jeśli ktoś mógł przygotować i zrealizować taką akcję, to jedynie ludzie z wywiadu. Milicjanci wykonywali tylko jakieś zadania pomocnicze. Oni mogli nawet nie wiedzieć, kogo pilnują - tłumaczył Czesław Kiszczak. 
- A pan wie coś na ten temat, słyszał pan o tym pobycie? - spytał Witek.

- Nie, ja nie. Mnie nie było jeszcze wtedy w ministerstwie. Wtedy rządził tam Milewski, ale on już nie żyje. Wielu ludzi już nie żyje, ale przypominam sobie, że były tam jakieś nasze wille, takie konspiracyjne, jak w Magdalence, z których korzystaliśmy czasami.

- A gdzie były te wille? - nie dawaliśmy za wygraną.

- Gdzieś w okolicach Szczytna, niedaleko Szczytna. Ale o pobycie tych terrorystów nic nie wiem - krótko uciął generał.

- Kto może wiedzieć więcej? - dopytywał się Witek.

- Spytajcie generała Pożogi, on szefował wtedy wywiadowi. - Tym razem twarz generała nie wyrażała sympatii wobec sugerowanego nam rozmówcy.

- Będzie chciał rozmawiać?

- Nie wiem, ale spróbujcie.

- Co pan myśli o tym dokumencie?

- Wygląda na prawdziwy - stwierdził generał.

- A czy ma pan jakąś teorię na temat tego, kim może być Polak, który zgłosił się do ambasady RFN w Warszawie? - zapytał Przemek. [...]

- Pamiętam, że w tamtym czasie była jakaś sprawa ze zdradą naszego oficera, oczywiście kogoś dużo mniej ważnego niż Kukliński. Chodziło o współpracę z Niemcami. Nie pamiętam dokładnie, ale było coś takiego. - Generał był przekonujący.

- To mógł być ten sam oficer, który proponuje dyplomatom informacje o członkach RAF? - dociekaliśmy.

- Nie wiem. Możliwe, ale naprawdę nie wiem. Nie śledziłem tej sprawy. Ja w tym czasie zajmowałem się innymi rzeczami. Jeszcze raz mówię, musicie znaleźć ludzi z Jedynki MSW. Oni będą wiedzieli, ale czy zechcą z wami gadać?

Po rozmowie z generałem Kiszczakiem mgliste zarysy naszych domysłów zaczęły przybierać bardziej wyraźne kształty. Było to jednak za mało, aby rozwikłać tajemnicę pobytu terrorystów z RAF w Polsce.

Za mało, aby poważnie kogoś oskarżyć. [...]

- Witek, dlaczego on powiedział nam o tych willach na Mazurach? - Głos Przemka był pełen wątpliwości.

Witek sięgnął do torby i wyciągnął z niej kartonową teczkę.

- ...i zdaje się, że miejsce, o którym mówił, na mapie oznaczone jest numerem sześć?

- Zgadza się. [...]".

I dalej fragmenty rozmowy z Peterem Juergenem Bockiem z RAF dotyczące możliwej współpracy terrorystów (a tym samym Stasi) z polskim MSW:

"[...] Czy miał pan kontakty z polskimi służbami specjalnymi?

Nie było właściwie kontaktów z naszej strony. O ile pamiętam, doszło do nich może dwa lub trzy razy, gdy byliśmy przejazdem, robiliśmy na przykład tak, że lecieliśmy do Warszawy samolotem z Brukseli. W Warszawie wyszliśmy z lotniska do biura podróży i kupiliśmy tam bilety na samolot, o ile sobie przypominam, z Warszawy do Bukaresztu, potem polecieliśmy do Bukaresz$\mathrm{tu}$, potem znowu wysiedliśmy i wreszcie $\mathrm{w}$ Bukareszcie zarezerwowaliśmy 
lot do Bagdadu. Tak, aby nikt nie mógł za nami podążyć. Powiem tak: blok wschodni dobrze wiedział, kto tak podróżuje. Zaproponowano nam, że będą udawać, iż nic nie widzieli, jeśli udzielimy im odpowiedzi na kilka pytań. My powiedzieliśmy jasno: „Nie pracujemy dla was”. Oni odpowiedzieli wtedy, że nie dadzą nam $\mathrm{w}$ takim razie przejechać, my na to: „W porządku, $\mathrm{w}$ takim razie przejedziemy inaczej, ale nie pozwolimy się szantażować $\mathrm{w}$ ten sposób" $[\ldots]$

Mamy tutaj dokument, z którego wynika, że w ambasadzie RFN w Warszawie działał szpieg Stasi. Ten człowiek przekazał informacje o waszym pobycie na Mazurach.

Nam zależało przede wszystkim na tym, ażeby nas nie odkryła Federalna Służba Wywiadowcza (Bundesnachrichtendienst). Wiemy, że również w urzędach w Polsce, Rumunii, Jugosławii znajdowali się donosiciele. Trudno wychodzić z założenia, że każdy może być szpiegiem, nie moglibyśmy z nikim rozmawiać, z takim podejściem nie zaszlibyśmy daleko.

Ale proszę spojrzeć na dokument, mówimy o czymś innym. W tym dokumencie zostało podane, że pan jako członek RAF długo przebywał w Polsce, w pobliżu Mrągowa na Mazurach.

To nieprawda. Tu może być tak napisane, jednak ja po operacji - podejrzewano u mnie raka, jednak okazało się, że to był tylko wrzód - przebywałem początkowo w Bagdadzie, później w kilku innych miastach. Okres rekonwalescencji spędziłem w Algierii, a nie na Mazurach.

Ten dokument jest fałszywy? Jak pan myśli, dlaczego Stasi produkowała takie dokumenty?

Widziałem setki takich dokumentów, ponieważ współpracuję ze „Spieglem". Już wspominałem wcześniej, jaki był zamiar Stasi. Oni chcieli wiedzieć, z kim mamy kontakty. Byli oczywiście ludzie, którzy chcieli prowokować na łamach prasy. [...]". 